Article

Ruud De Mooij*, Shafik Hebous, and Milena Hrdinkova

\title{
Growth-Enhancing Corporate Tax Reform in Belgium $^{\star *}$
}

https://doi.org/10.1515/ntaxj-2018-0004

Received Mar 16 2017; accepted Jan 292018

\begin{abstract}
Until 2018, Belgium had a unique corporate income tax system due to its notional interest deduction, also known in public finance literature as the allowance for corporate equity. At the same time, it had one of the highest corporate tax rates in Europe at 34 percent. The latter came under severe pressure to reform and, as of 2018 , the government has started to reduce the rate, gradually to reach 25 percent in 2020. The reduction is accompanied by other measures, including a limitation of the notional interest deduction. This paper argues that the lower CIT rate is likely to be conducive to economic growth. Yet, the effects on growth would have been more favorable if the notional interest deduction would have been strengthened, rather than diminished.
\end{abstract}

JEL Classification Numbers: H25; H32; H71

\section{Introduction}

Like many other countries, Belgium faces an important challenge in designing its corporate income tax (CIT) system. On the one hand, the CIT is an important revenue source and plays a key role in ensuring neutrality of the taxation of business income. On the other hand, the system needs to adapt to the emerging international trends. For instance, international initiatives in the OECD and the EU require adjustment in the tax treatment of multinational corporations. Moreover, tax competition urges

${ }^{\star}$ Corresponding Author: Ruud De Mooij: International Monetary Fund.; Email: RDeMooij@imf.org

Shafik Hebous: International Monetary Fund.; Email: shebous@imf.org

Milena Hrdinkova: Ministry of Finance in the Czech Republic

$\star \star$ The views expressed here are those of the authors and do not necessarily represent the views of the IMF, its Executive Board, or IMF management, nor of the government of the Czech Republic countries such as Belgium to keep tax rates in line with other countries. Indeed, the downward trend of the CIT rates in Europe continues. The new French government, for example, has announced a CIT reduction to 25 percent by 2022. The UK, which currently has the lowest CIT rate of 19 percent in the G20, announced a cut to 17 percent by 2020. These countries aim to design a CIT system that is competitive and efficient, and would enhance economic growth.

This article explores a growth-enhancing CIT reform strategy for Belgium, as representing a small open economy in the heart of Europe. While several issues that will be discussed apply equally to other countries in Europe or the OECD, Belgium is unique in a few respects. First, before 2018, Belgium was among the very few countries in the world that neutralized the debt bias inherent in many CIT designs; it did so through granting a notional interest deduction (NID) for equity capital. Second, this system was combined with one of the highest statutory CIT rates in Europe of almost 34 percent. Finally, Belgium has a few other characteristics that are relatively uncommon, such as a very generous innovation box, absence of a consolidation regime for corporate groups, and no capital gains tax for individuals. These features make it worthwhile to explore how reform could be designed in a way to encourage growth and enhance neutrality.

In January 2018-after the first draft of this article was written-the Belgian government implemented the first stage of a significant multi-year reform effort in its CIT. It comprises a reduction in the CIT rate to 29.58 (with a further reduction to 25 percent foreseen in 2020), introduction of a tax consolidation regime for corporate groups, and adoption of new rules from a recent EU Directive against tax avoidance. Apart from this, the government also reduced the scope of the notional interest deduction as a means to broaden the CIT base.

This paper compares these changes against a set of measures that would target the reform to enhance economic growth and mitigate tax distortions between corporate and non-corporate businesses. The paper argues that several aspects of the reform are desirable in this regard: reduction in the CIT rate, repeal of some exemptions and 
deductions, the group regime, and several anti-tax avoidance provisions. Yet, the growth effects could have been stronger if the NID would have been enhanced, rather than limited. Moreover, neutrality could have been strengthened by adopting a capital gains tax and a higher tax on dividends.

This paper is structured as follows. Section 2 describes the major elements of business taxation in Belgium before 2018, including the CIT rate, CIT base and the treatment of Multinational Companies (MNCs). Section 3 discusses the notional interest deduction (NID) regime. Section 4 presents the recent international development in the CIT and its impact on Belgium, while Section 5 discusses the options for growth-enhancing reform in the Belgian CIT. Section 6 compares the recent tax CIT reform with our set of growth-enhancing measures.

\section{The corporate tax system}

Belgium's CIT is a relatively important revenue source. In 2014, the CIT raised 3.2 percent of GDP. This is above the EU average of 2.3 percent of GDP (left panel of Figure 1). A significant share of CIT payments comes from small firms, partly reflecting a relatively high share of SMEs that are organized as legal corporate entities in Belgium (see further below). Of course, this also means that these SMEs do not pay the personal income tax (PIT). It is also instructive to look at CIT revenue productivity-defined as the CIT revenue-to-GDP ratio divided by the statutory CIT rate (right panel of Figure 1). This indicator reflects the CIT revenue as a percent of GDP generated per each point of the CIT rate. With revenue productivity close to 0.1 percent of GDP (approximately €400 million per point of CIT), Belgium is slightly below the European average of 0.11. This may partly reflect relatively generous incentives that narrow the CIT base in Belgium; it can also reflect profit shifting to low-tax jurisdictions, induced by the relatively high Belgian CIT rate. The design features of the Belgian CIT are discussed in greater detail below.

\subsection{Corporate tax rates}

The statutory CIT rate is high by international comparison (Figure 2). In 2017, the standard rate was 33 percent, but a 3 percent austerity surcharge (imposed since 1991) made the overall applicable CIT rate 33.99 percent. In comparison, the average CIT rate in the EU was 22.5 percent; it was 24.3 percent in the Euro area; and in the OECD, it was
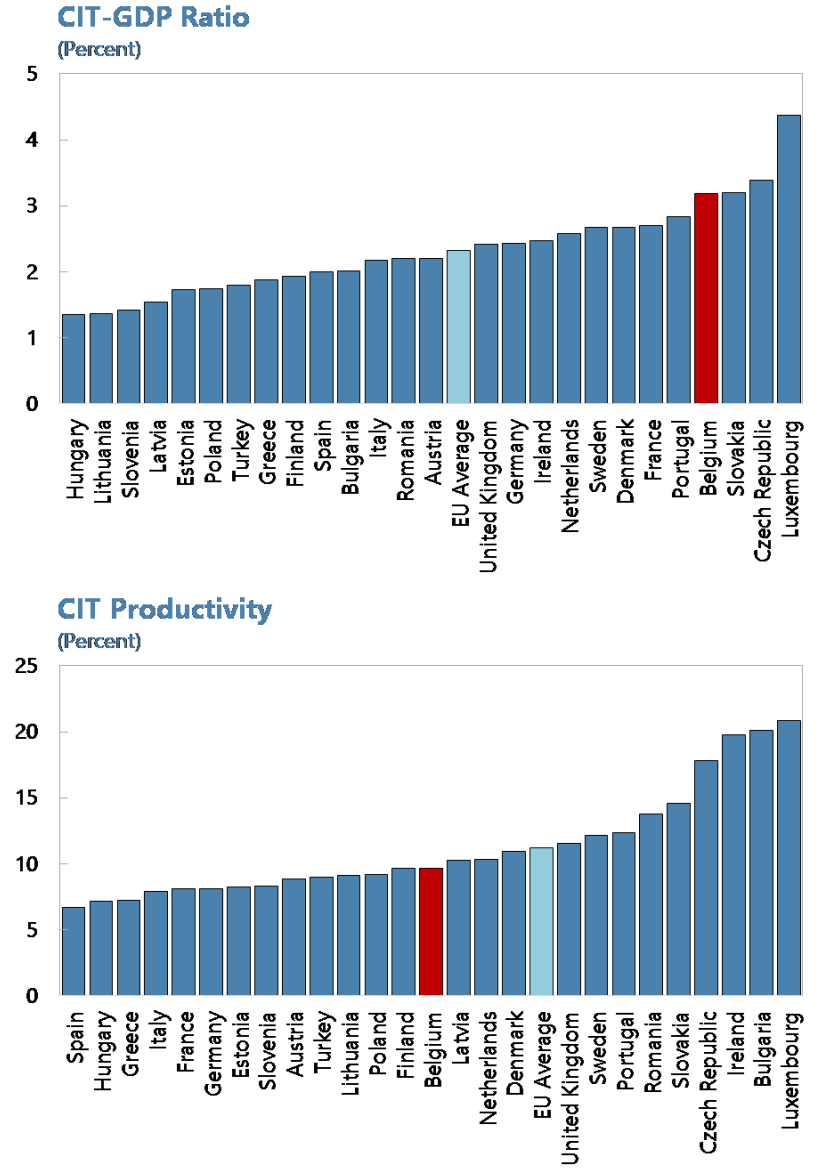

Source: EU Tax Statistics and IMF staff calculation. CIT productivity $=(\mathrm{CIT}$ revenue $/ \mathrm{GDP}) / \mathrm{CIT}$ rate

Figure 1: CIT Revenue and Revenue Productivity, 2014

24.7 percent. The only four other OECD countries with CIT rates exceeding 30 percent were France, Germany, Japan and the US. As noted in the introduction, the Belgian government reduced its CIT rate to 29 percent in 2018 (plus a 2 percent surcharge, which brings the overall rate at 29.58 percent) and further to 25 percent in 2020 (with full repeal of the surcharge). While most countries adopt a single CIT rate for all corporate income, Belgium employed a special progressive rate structure for corporate profits below $€ 322,500$, with the lowest rate of 24.98 percent applied to incomes up to $€ 25,000$, a rate of 31.93 percent for income between $€ 25,000$ and $€ 90,000$ and a rate of 35.54 percent between $€ 90,000$ and $€ 322,500 .{ }^{1}$ Also, this provision was

1 A detailed discussion of the CIT incidence, i.e., whether the CIT burden is ultimately born by shareholders or transferred into lower wages, is beyond the scope of this paper. For a discussion, see Fuest et al. (2015). 


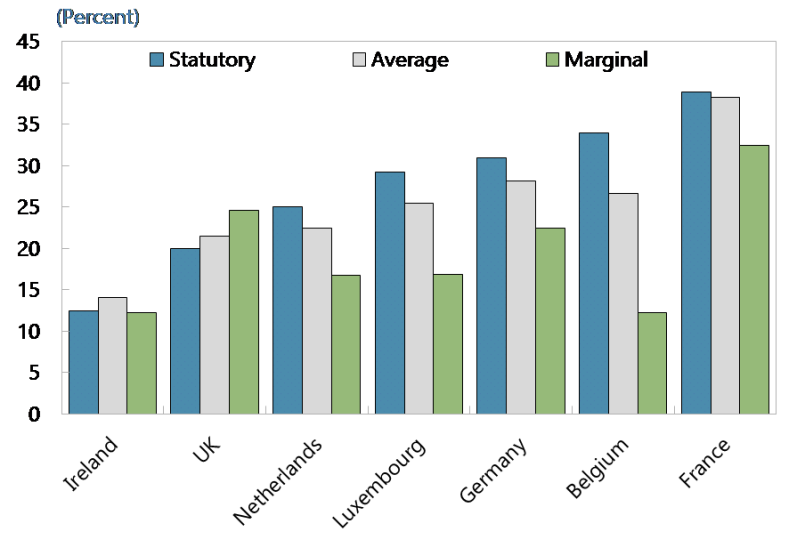

Source: Zentrum für Europäische Wirtschaftsforschung (2016).

Figure 2: Statutory and Effective CIT Rates in Belgium and Comparator Countries

changed in 2018 into a single reduced rate of 20 percent for corporate profits below €100,000.

The impact of taxation on investment and revenue is determined by effective tax rates. These depend not only on the statutory CIT rate, but also on the elements of the tax base, such as depreciation allowances, inventory valuation, interest deductibility and tax incentives. Two effective tax rate measures are generally used to infer the impact of the CIT system on investment: ${ }^{2}$ (i) the marginal effective tax rate (METR), which is derived from the user cost of capital; it measures the tax burden imposed on an investment that just meets the required rate of return to be viable to undertake; and (ii) the average effective tax rate (AETR), which matters for investment choices that are inframarginal, for example, the location choice of multinational corporations (MNCs) or investment by firms facing credit constraints. It is also indicative of the amount of fiscal revenue collected.

Based on the data for 2015, Figure 2 shows that the AETR in Belgium of 26.7 percent was lower than the statutory CIT rate. The AETR was higher than the EU average

2 These are forward looking effective tax rates (ETRs), based on simulations of the prevailing tax code. They provide insight into the incentive effects of taxation. Alternatively, backward looking ETRs are based on realized tax payments and are generally used to picture the distribution of taxation across firms. Those measures also capture the issues of non-compliance and tax avoidance. Backward looking tax rates reported by the European Commission until 2012 (labeled implicit tax rates) suggest that the corporate tax burden in Belgium is in the mid-range of the EU (lower than, e.g., Austria, France, and Italy; similar to the United Kingdom and Portugal; and higher than Ireland and the Netherlands). See https://ec.europa.eu/taxation_customs/business/ economic-analysis-taxation/taxation-trends-eu-union_en. of 21 percent and exceeds the rates in Ireland, the Netherlands and the United Kingdom (but is lower than the 28.2 percent in Germany and the 38.3 percent in France). Hence, the CIT system in Belgium entailed relatively large disincentives for discrete foreign direct investment (FDI). The METR in Belgium was relatively low compared to the other European countries, reflecting the impact of specific design features such as the notional interest deduction (see below). Indeed, the rate of 12.5 percent was among the lowest in the EU and similar to the level in Ireland. ${ }^{3}$ Thus, while fewer multinationals might have chosen Belgium as the location for their activities, marginal investment distortions are relatively small, implying that additional investment by firms already residing in Belgium was discouraged less than elsewhere.

\subsection{Corporate tax base}

The corporate tax base in Belgium follows common international practices. Legitimate business expenses are deductible. Tax depreciation allowances are relatively generous for some types of machinery (with accelerated straight-line depreciation available at 33 percent per year) and buildings (where straight-line depreciation for industrial buildings is allowed at 5 percent per year). For intangible assets, depreciation is in line with other countries.

Several features aim to encourage innovation. First, there is a specific tax credit for research and development (R\&D), meaning that firms receive a discount on their tax liability that is proportional to their R\&D expenses. This effectively subsidizes R\&D costs by between 5 and 8 percent. Second, there is an exemption from the payroll withholding tax for qualified researchers. This reduces the cost of the labor component of R\&D by 15 to 20 percent. Finally, Belgium has a so-called innovation box. ${ }^{4}$ It implies that income from qualified intellectual property (IP) is separated from other income and is liable for an 85 percent exemption from the CIT. Hence, only the remaining 15 percent of that income is taxable at the statutory CIT rate of 34 percent; the effective rate on this income is therefore only 5.1 percent. This effective rate is low compared to other coun-

3 The METR is sensitive to assumptions about the interest rate. The calculations presented here assume a fixed interest rate of 5 percent for all years and countries. If the interest rate in the calculation would be based on the actual rate in Belgium (and thus, equal to the notional interest deduction), the METR would be equal to zero-as theory suggests.

4 These are also sometimes referred to as IP box or patent box regimes. 


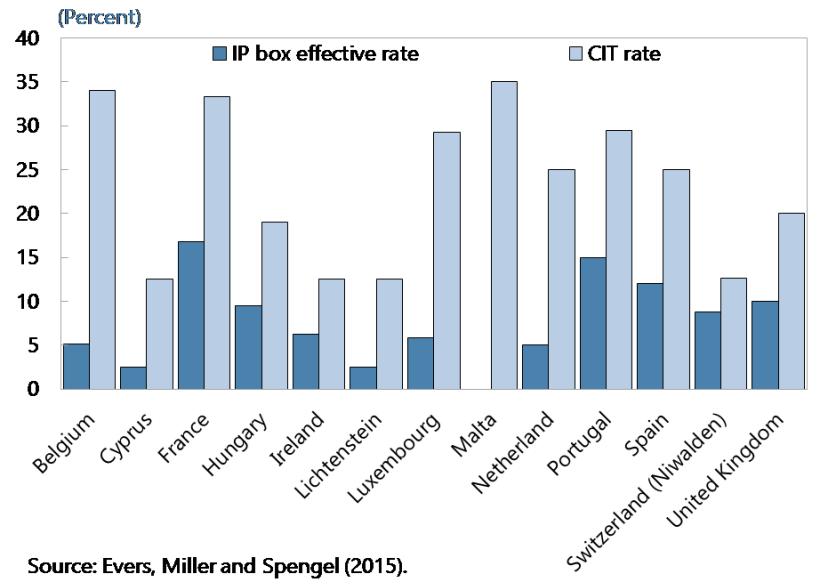

Figure 3: Effective Tax Rates in Innovation Box Regimes in Europe

tries that have an innovation box (Figure 3), and it will become even lower, reaching 3.75 percent, for a statutory CIT rate of 25 percent. Virtually all benefits under this scheme are enjoyed by large enterprises in the manufacturing sector.

Loss offset provisions are comparatively restrictive. Losses can be carried forward indefinitely, but without interest. There is no loss carry backward-a provision that is available in only few European countries. Somewhat exceptional is that Belgium does not allow for group taxation, that is, the tax results of companies in a group cannot be consolidated. Such consolidation would allow for the immediate offset of losses in one subsidiary against profits elsewhere in the group. It is especially attractive for large businesses. Group taxation is available in most Western European countries (see Annex 1).

The overall revenue forgone from base narrowing measures in the CIT is moderate, but non-negligible. This can be drawn from the annual tax expenditure review. The latest available analysis for 2012 (Federal Public Service Finance, 2016) suggests that overall corporate tax expenditures in Belgium are 12.8 percent of CIT revenue. Approximately one quarter of this is due to R\&D tax incentives; another 14 percent is due to the innovation box. The remainder is associated with special investment tax incentives and exemptions for certain entities, such as intermunicipal associations and firms in the audio-visual arts sector.

Since 2006, Belgium allows for a notional interest deduction (NID). ${ }^{5}$ It aims to neutralize the CIT treatment of

5 The NID replaced a previous regime known as "Coordination Center Regime" that offered multinationals lower taxes by using an alternative method for determining the taxable income (the so-called debt and equity by supplementing the deductibility of interest with a deduction that is the product of the total book value of equity (with some corrections) and a notional interest rate. The latter is derived from the average monthly Belgian government bond rate of the preceding fiscal year. The NID rate for 2017 is 1.13 percent; it is 0.5 percentage points higher for small companies. Since 2013, unused NID can no longer be carried forward. The implications of the NID, including for revenue, financial stability, and economic growth, are further discussed in section 3.

\subsection{Tax neutrality across business and investment income}

About 98 percent of all firms in Belgium are purely domestic; they employ more than 70 percent of all Belgian employees. For them, the CIT serves as a backstop for the PIT, that is, it aims to limit tax avoidance opportunities vis-à-vis the PIT. In particular, Belgian business income from unincorporated small and medium-sized enterprises (SMEs), such as sole proprietorships, is taxed under the progressive PIT, with rates ranging from 25 to 50 percent. $^{6}$ In contrast, the income earned by a closely-held corporation is taxed differently. The owner-director of such a corporate business is obliged to pay a minimum director's remuneration of $€ 24,500$. This income is deductible for the CIT but taxed as labor income under the progressive PIT. The remaining income is first subject to the progressive CIT. Then, if this corporate income is distributed to the ownerdirector in the form of dividends, it is subject to an additional dividend tax of 30 percent. However, when corporate income is retained within the firm and at some stage realized as a capital gain, the entrepreneur can escape this distribution tax, since there is no personal tax on capital gains. ${ }^{7}$ If the CIT would be absent or reduced significantly, entrepreneurs could change the legal form of their busi-

cost-plus method). The system was considered as harmful tax practice by the EU code of conduct on business taxation, and hence, was repealed.

6 The analysis here abstracts from social security contributions. These differ between employees, corporate businesses and noncorporate businesses and might also affect the incorporation decision.

7 Liquidation proceeds (i.e., returns of accumulated profits over and above paid up capital upon liquidation of a company) are subject to personal tax. A short-term (speculative) capital gains tax was in place in 2016. 


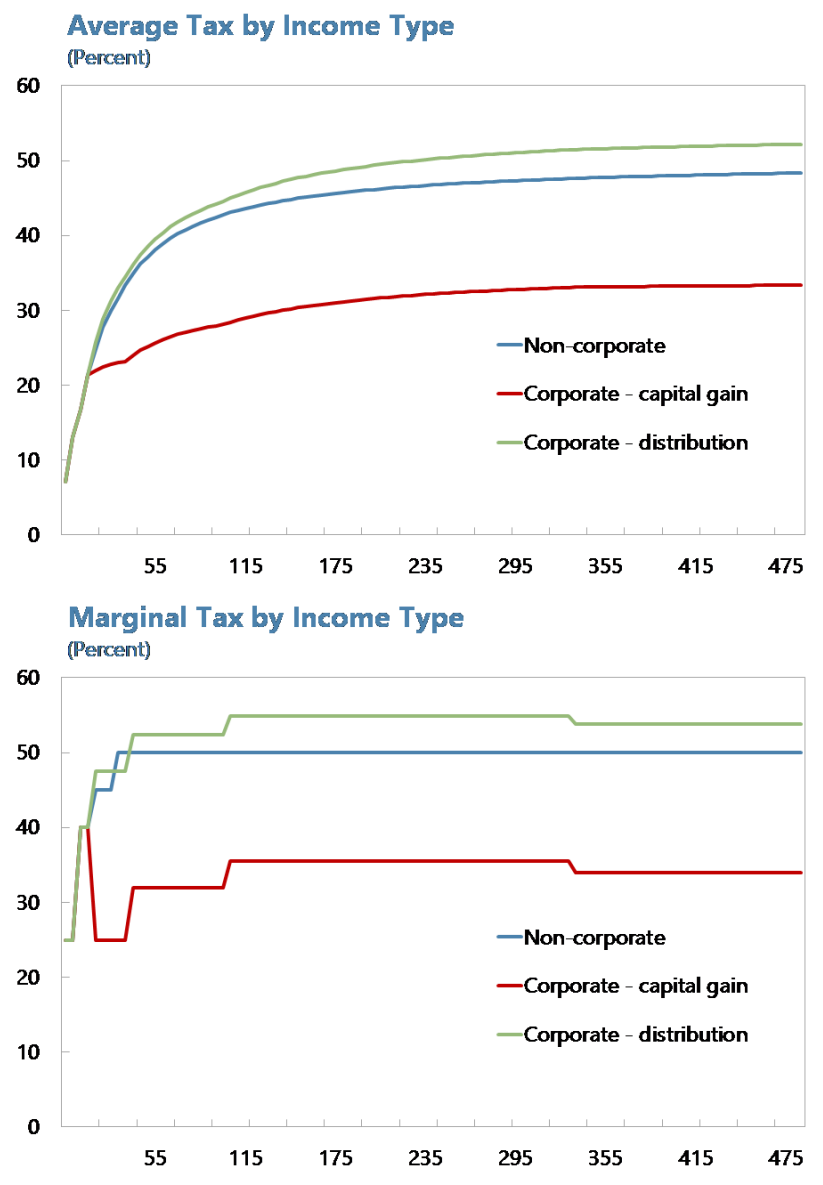

Source: Author calculations

Figure 4: Average and Marginal Tax on Different Types of Business Income

ness and reduce their tax liability, which would be much higher under the PIT. ${ }^{8}$

The Belgian tax system already creates de facto incentives for individuals to register as a corporation and to accumulate retained earnings, rather than distributing dividends. To illustrate the properties of current system in Belgium, Figure 4 compares the average (left panel) and marginal (right panel) tax burden on income derived from three forms of businesses along the income distribution between $€ 10,000$ and $€ 500,000$ :

- A non-corporate business that is subject to the progressive PIT

8 Evidence for Europe points to significant shifts in the legal form of businesses due to tax differences between corporate and noncorporate businesses, see De Mooij and Nicodeme (2008).
- A corporate business that pays the minimum director's remuneration of $€ 24,500$ and then distributes all remaining profit as dividends

- A corporate business that pays the minimum director's remuneration of $€ 24,500$ and then retains the profit in the firm and realizes it at a later stage as a capital gain.

Figure 4 shows that the average and marginal tax burden is quite similar for a non-corporate business and a corporate business that pays dividends. Hence, there is little reason for entrepreneurs to run their business in either the corporate or the non-corporate legal form; nor is there reason to pay dividends instead of wages. However, Figure 4 also shows that a corporate business that retains profit and realizes income as a capital gain is taxed much lighter than others. This reflects the absence of a personal capital gains tax in Belgium. This leads to a lock-in effect (capital gets locked in existing companies), which distorts the allocation of capital, thus inducing efficiency loss. Although Belgium is not unique in this regard, only four other European countries leave personal capital gains entirely untaxed (Malta, Cyprus, Czech Republic, and Luxembourg).

This tax incentive may be responsible for the gradual but significant increase in the share of Belgian businesses run in the corporate form over the last few decades. A report by the High Council of Finance in 2014, for instance, shows that in 1983, less than 20 percent of all businesses were incorporated, while more than 80 percent were run in the non-corporate form. In 2012, the share of businesses in the corporate form had risen to over 50 percent and was still increasing. Today, many professionals and selfemployed people, such as lawyers, doctors, architects, engineers, contractors, journalists, interpreters, and so on, are organized as closely-held corporations. The economic implications of this tax-induced development in business form may go beyond the pure fiscal aspects and create welfare losses due to organizational inefficiencies and misallocation of capital. The lower CIT rate as part of the reform is likely to exacerbate this distortion.

\subsection{Treatment of multinational corporations}

Belgium's CIT system features common international tax rules. Companies that receive dividends or qualified capital gains from abroad benefit from a 95 percent participation exemption to avoid double taxation (with the remaining 5 percent taxable in Belgium). Foreign subsidiaries and branches in Belgium are taxed on their source income through the CIT and possibly withholding taxes on div- 
idends, interest and royalties. These latter taxes are often agreed upon in 93 bilateral tax treaties that Belgium has signed with other countries. The terms of Belgium's treaties (such as withholding tax rates) are consistent with international conventions and in line with those in many other tax treaties.

In the past, Belgium has used various targeted tax incentives to attract foreign direct investment from MNCs, such as the regime for coordination centers before 2006, the NID after 2006 (see below), the innovation box, and specific rulings such as an excess profit tax ruling. This strategy has been relatively successful in the past. For instance, the inbound stock of FDI is approximately 100 percent of GDP in 2015 (per the IMF Coordinated Direct Investment Survey). This is much higher than in most other European countries. However, the outbound stock of FDI from Belgium is of equal size, and around 35 percent of the outstanding inbound FDI is in special purpose vehicles (referred to as "captive financial institutions and money lenders" in the national accounts) (Duprez and Van Nieuwenhuyze, 2016). This suggests that a large share of FDI comprises purely financial flows running through Belgium-rather than greenfield investments that contribute to the Belgian economy. These financial flows may be a part of the tax planning strategies by MNCs and create negative spillovers on the tax base of other countries. The tax incentives have therefore recently come under increased international scrutiny (see next section). In response to this, Belgium has already revised some of its incentives, such as the excess profit ruling.

The Belgian tax code contains modest anti-avoidance provisions to protect its CIT base against base erosion and profit shifting by MNCs. For instance, its transfer pricing regulations are consistent with OECD guidelines, and there is a general anti avoidance rule that can be used to challenge aggressive forms of tax planning. However, compared to other countries, the current anti-avoidance provisions are relatively modest. For instance, Belgium adopts relatively weak interest-deductibility limitations (which aims to limit base erosion through debt shifting) and applies very limited controlled foreign corporation rules (CFC rules, which would bring into tax the passive income earned in low-tax foreign affiliates of Belgian MNCs). ${ }^{9}$

9 In 2015, Belgium introduced the so-called "Cayman tax"-a limited form of CFC rule whereby legal constructions are deemed to be tax transparent and the income of such legal constructions is taxable in Belgium.

\section{The Notional Interest Deduction}

The Belgian NID resembles what the public finance literature generally refers to as the Allowance for Corporate Equity (ACE). Inspired by Boadway and Bruce (1984), who proposed to replace interest deductibility with a notional deduction for all capital, ACE supplements the current deductibility of interest with a similar deduction for the normal return on equity. It has been quite widely advocated by economists including, for instance, in the Mirrlees review for the UK (2013) and more generally by the IMF staff (IMF, 2016a). This advocacy originates in the neutrality aspects of the ACE, which we briefly discuss in this section in the Belgian context. ${ }^{10}$

\subsection{Debt bias}

Debt bias occurs if only interest is deductible for the CIT, but not the normal return on equity. It provides an incentive for companies to excessively finance their investments by debt, rather than equity-with important implications for welfare and financial stability. Empirical evidence indeed finds a significant impact of CIT systems on corporate financial structures (IMF, 2016a). The NID aims to alleviate this financial distortion by neutralizing the treatment of debt and equity. Indeed, by granting a deduction for the normal return on equity, the debt bias induced by the ordinary CIT system is removed.

Empirical evaluations show that the Belgium NID has been effective in lowering corporate leverage ratios, both in financial and non-financial firms. Thus, it has contributed to the resilience of the Belgian economy by mitigating instability risks (Burggraeve et al., 2008; Kestens et al., 2012; Princen, 2012; Panier et al., 2015). These analyses have been conducted for only non-financial companies. To assess the implications for the banking sector, we present new estimates based on the synthetic control method. The challenge of assessing the impact of the NID on bank leverage is that the counterfactual is not observable, that is, what would have happened to bank debt had Belgium not introduced the NID in 2006? This challenge can be addressed using a recent empirical technique-the synthetic control method-whereby the pre-NID consolidated debt-asset ratio in the banking sector in Belgium is

10 De Mooij and Devereux (2011) compare an ACE with a comprehensive business income tax regime that denies interest expense deduction. Brekke et al. (2017) study the neutrality properties of the ACE under imperfect competition. 


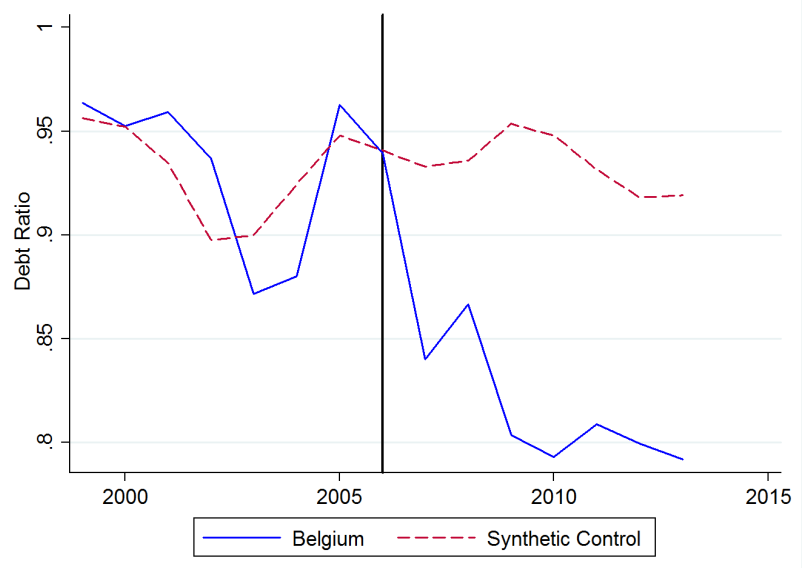

Figure 5: The NID and Bank Leverage in Belgium

replicated using a weighted average of the same debt ratio in non-NID countries (called 'control units'). ${ }^{11}$ In the exercise presented here, the source of the data on banks is Bankscope, and the sample includes 49 non-NID countries as well as Belgium. The weights are determined optimally by minimizing the distance between the average Belgian bank debt ratio and a synthetic debt ratio predicted using the predicting variables that are typically used in the literature. These predictors are at the country-year-level and include, for example, the statutory CIT rate, the interest rate, and profitability. Having constructed a variable mimicking the Belgian debt ratio before the reform (i.e., the synthetic control), the predicted evolution of the synthetic control after the reform gives a measure of the counterfactual debt ratio in Belgium without the NID. Figure 5 shows that the actual Belgian average debt in the banking sector considerably diverged from the counterfactual debt after 2006, suggesting that the NID has been highly successful in reducing bank leverage, with a magnitude reaching 13.7 percentage points. Similar findings are reported by Schepens (2016). Hebous and Ruf (2017) report even bigger effects for non-financial MNCs in Belgium.

\subsection{Investment}

As the NID charges no tax on projects whose return equals the cost of capital, the effective marginal tax rate is reduced to zero. This offers a powerful stimulus for investment compared to a system without such a provision. Figure 6 shows the predicted impact of the NID on invest-

11 Abadie et al. (2010) provide a detailed explanation of the synthetic control method.

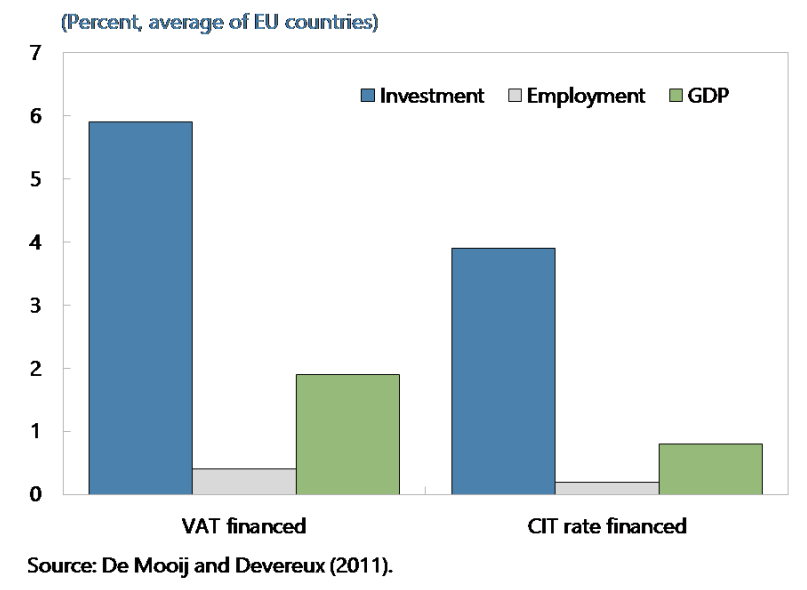

Figure 6: Simulating the Macroeconomic Impact of the NID in the EU

ment, employment and GDP in the EU, based on simulations with a computable general equilibrium model (see De Mooij and Devereux, 2011). Here, the NID is financed in a revenue-neutral fashion under two alternative offsets: (i) an increase in the VAT; or (ii) a higher statutory CIT rate. The simulations suggest that investment in the EU countries rises by 6 percent if the VAT is used to finance the NID; it rises by 4 percent if the statutory CIT rate is increased. Employment would also rise under both scenarios, while GDP expands by, respectively, 2 and 1 percent. These results suggest that the NID is much more important for growth than the CIT rate. The NID has therefore recently received increased attention from countries and, for instance, was the main motivation for its introduction in Italy and its inclusion in the Common Consolidated Corporate Tax Base in the EU. However, the empirical evidence on investment effects of the ACE is scarce, and the outcomes of the available empirical studies are mixed (see, e.g., Hebous and Ruf 2017; Aus dem Moore 2014).

\subsection{Tax planning}

A concern with the Belgian NID is that it is widely used for international tax planning. To see how the mechanism works, consider an MNC that resides in country 1 and that wants to invest in a subsidiary in country 2. Instead of directly funding this investment, the MNC can finance a Belgian special purpose vehicle (SPV) with equity; subsequently, the SPV transfers these funds to the subsidiary in country 2 in the form of a loan. By charging an interest rate on the loan that is equivalent to the NID rate prevailing in Belgium, no tax is due by the SPV in Belgium. At the same time, any dividend repatriation to the parent will be typically exempt in country 1 , while the interest paid by the 
subsidiary is generally deductible in country 2 . Thus, the MNC escapes tax in all three countries by using the SPV in Belgium. While the Belgian government neither suffers nor benefits from this SPV, other countries lose from its use.

The importance of this spillover from the NID is visible in FDI data: Duprez and Van Nieuwenhuyze (2016) note that: "FDI in Belgium comprises a large proportion of "capital in transit," i.e., capital that enters the country and in most cases leaves again immediately. When that capital enters Belgium, it often takes the form of equity, for tax reasons: when it leaves Belgium, it does so in the form of an (intra-group) loan." Overall, around 40 percent of all NID deductions in Belgium can be attributed to these SPVs (High Council of Finance, 2016). Given the negative spillovers to the tax base of other countries, the question is whether this generates any benefit for the Belgian economy. Unfortunately, no study is available that estimates the contribution of these SPVs to Belgian GDP. ${ }^{12}$ However, what is clear from the data by the National Bank of Belgium is that the operations of these SPVs are almost entirely disconnected from the Belgian banking system. This feeds suspicion that these "transit flows" might indeed bring little gain to the country.

There are several remedies against tax planning, which both Belgium and other countries can adopt. Suggestions for reforms in Belgium are discussed in, for example, Zangari (2014). For other countries, it is important to note that the international tax planning induced by the ACE is reminiscent to classical debt shifting. Indeed, international differences in CIT rates also induce firms to shift debt into high-tax countries and equity into low-tax countries. Countries have increasingly started to protect their tax base against this debt shifting through the adoption of thin capitalization rules and earnings-stripping rules. These anti-avoidance measures could also be effective against tax planning through the NID.

\subsection{Fiscal costs}

Estimating the fiscal costs of the NID is complex, especially in light of important behavioral responses. In 2014, the sum of all NIDs multiplied by the CIT rate was around

12 For instance, for the Netherlands Kerste et al. (2013) assessed the economic impact of Dutch SPVs, which to a large extent are related to tax planning. They find that $12,000 \mathrm{SPVs}$ create a total of between 8,800 and 13,000 jobs and contributed between $€ 3$ billion and 3.4 billion to the Dutch economy (between 0.4 and 0.5 percent of GDP). The sum of the inflow and outflow of capital through these SPVs was $€ 8,000$ billion (1240 percent of GDP).
$€ 4.5$ billion, equivalent to 35 percent of actual CIT revenue. However, this figure does not adequately represent the overall fiscal cost of the NID for at least two reasons. First, as noted before, approximately 40 percent of the NID in Belgium is used by SPVs. They are present in Belgium only because of the existence of the NID and it is likely that they would disappear if the regime were repealed. Moreover, these NID provisions are exactly offset by an equivalent addition to the tax base due to taxable foreign interest income. The net revenue impact of the NID used by the SPVs is therefore zero. This implies that 40 percent of the gross fiscal cost of the NID should be subtracted from the number above. Second, for ordinary firms (other than SPVs), empirical evidence suggests that the introduction of the NID has raised the equity/asset ratio from 40 to 60 percent (Hebous and Ruf, forthcoming). Conversely, the stock of debt (and associated interest deductions) is noticeably smaller. Thus, using the current equity stock in computing the revenue impact of the NID significantly overestimates the true revenue loss, since the fiscal benefits from lower interest deductions should also be accounted for. IMF (2016a) estimates that this element leads to an overstatement of the revenue loss by 50 percent. ${ }^{13}$ With these modifications, the net revenue effect would likely be less than one third of the gross figure mentioned above, that is, close to 10 percent of CIT revenue. This is close to the estimates of the revenue cost of an ACE in an average OECD country, computed in IMF (2016a): using accounting data for 2012 and 2013, they arrive at an average cost of between 10 and 12 percent of CIT revenue. ${ }^{14}$

\section{Forces Shaping Corporate Tax Reform}

\subsection{International developments}

Recent international initiatives have significant implications for the Belgian CIT design. Here, we discuss, respec-

13 This number might be even larger if the NID rate (at which equity is deducted) is lower than the corporate interest rate (at which debt is deducted).

14 For the coming years, the revenue cost of the NID is likely to be much smaller than 10 percent. Driven by the very low interest rate on government bonds, the NID rate for 2017 is set at 1.131 percent; and the rate for 2018 will be even lower, at 0.237 percent. These rates are much lower than the 2.63 percent in 2014-to which the numbers above refer. Hence, the NID in 2018 would effectively have negligible revenue implications for that year. 
tively, the OECD/G20 initiative on base erosion and profit shifting (BEPS), decisions by the European Court of Justice (ECJ), and the EU Anti-Tax Avoidance Directive (ATAD).

- Under the BEPS initiative, concluded in November 2015, countries have agreed on a non-binding set of common guidelines and minimum standards to limit opportunities for international tax avoidance by MNCs. Belgium is committed to adopt at least the four minimum standards. The initiative has already led to amendments in the design of the Belgian innovation box. Another important element of BEPS is the multilateral instrument, which modifies the bilateral tax treaties along the lines of a common framework. This has been signed in June 2017 and Belgium has proposed 98 of its tax treaties for revision. A general anti-treaty abuse rule will be added to every treaty covered by the multilateral instrument.

- EU state aid rules have targeted various special regimes across Europe, including prominent cases in Ireland, Luxembourg and the Netherlands. In Belgium, it has required the government to abolish the so-called excess profit tax ruling regime. That scheme reduced the CIT base of those companies who had received a discount for "excess profits" resulting from being part of an MNC. The European Commission (EC) classified it as inconsistent with the EU state aid rules, as it puts smaller competitors, who are not an MNC, on an unequal footing. 35 MNCs had enjoyed the relief and its repeal has been imposed with retroactive effect. ${ }^{15}$

- EU Directives provide concrete, binding rules that Belgium should implement. A recent one is the AntiTax Avoidance Directive ${ }^{16}$ (ATAD) adopted in June 2016. ${ }^{17}$ Mimicking the BEPS guidelines, it comprises five measures: (i) an interest deduction limitation; (ii) a limitation to the exemptions of foreign source income (so-called CFC rule); (iii) exit taxation; (iv) a general anti-abuse rule; and (v) solutions for hybrid mismatches. Especially the first three will im-

15 The Belgian government and some affected companies challenged the decision at the ECJ. The EC has faced criticism to impose the decision with retrospective effect, going back to its introduction in 2005. However, once deemed unlawful, the Commission must recover incompatible State aid including interest (for up to 10 years).

16 Council Directive (EU) 2016/1164 of 12 July 2016 laid down rules against tax avoidance practices that directly affect the functioning of the internal market.

17 ATAD will need to be implemented by 1 January 2019, except for the interest limitation rule, which may be postponed until 2024. ply a considerable change in Belgium's anti avoidance provisions, which-as noted before-are relatively lenient. ${ }^{18}$ For example, the limitation to interest deductibility can significantly affect several large multinational businesses and thus expand the Belgian CIT base. Additionally, the CFC rule (which would require the non-distributed income of a controlled foreign subsidiary or permanent establishment to be included in the tax base of the parent company in Belgium) and the exit tax (which would impose Belgian tax on unrealized capital gains when an asset is transferred abroad) provide potential for further base broadening in Belgium.

Although it has no immediate policy implications for Belgium, the common consolidated corporate tax base (СССТВ) proposal in the EU may affect the debate on CIT reform. First tabled in 2011 as an optional scheme for EU businesses, the new СССТВ was re-launched in October 2016 to replace the 28 different CIT regimes in Europe. It contains two elements which are proposed to be implemented sequentially: (i) a common corporate tax base (CCTB), that is, a set of common rules regarding depreciation, deductible costs and incentives; and (ii) consolidation of the accounts of a multinational corporation across countries - the consolidated base would then be divided between the Member states based on an apportionment formula, comprising three factors: $1 / 3$ for the value of tangible assets, $1 / 3$ labor (measured for one half by payroll and one half by the number of employees) and $1 / 3$ for the value of sales by destination. Each country could then apply its own CIT rate to the apportioned base. The СССТВ would be mandatory for multinational groups with a consolidated revenue exceeding $€ 750$ million per year; other firms might opt to be taxed either according to the CCCTB or the national CIT. The CCCTB can significantly simplify the CIT in Europe, thus reducing compliance costs and eliminating mismatches between national systems. It would also curb aggressive tax planning and remove the need for transfer pricing within the EU. Yet, the CСCTB would also involve new challenges, not least due to a significant re-allocation of tax bases across countries. Moreover, as tax will effectively be levied based on the formula factors, new distortions will arise in the location of these factors-and tax competition for attracting those factors with a low tax rate will remain.

18 There has also been a recent amendment of the Parent Subsidiary Directive, which disallows the participation exemption on taxdeductible profit distributions. 
Most elements of the proposed common base follow general design principles of the existing CIT systems in the $\mathrm{EU}$, for example, with respect to depreciation, loss carry forward, deductible expenses and anti-avoidance provisions vis-à-vis the external EU trading partners. Yet, two specific elements in the CCTB are worth mentioning. First, it allows for a super-deduction for R\&D costs: 150 percent of the R\&D expenditures are deductible for up to $€ 20$ million. The deduction is smaller for R\&D spending beyond that level and more generous for start-up firms without any associates. Second, the CCTB contains a so-called allowance for growth and investment (AGI), reminiscent to the Belgian NID. However, the AGI is applied to incremental equity relative to a base year and granted only for a 10 -year period. The AGI rate is, like the Belgian NID rate, linked to the government bond rate, but topped up with a risk premium of 2 percent. The AGI foresees anti-tax avoidance rules to safeguard against possible cascading effects and tax planning.

Adoption of the СССТВ would have major implications for the EU member states, including for Belgium. First, the common base will require scrapping some tax incentives while introducing others. Second, consolidation will automatically imply cross-border loss offset. This benefits multinational businesses but narrows the Europewide corporate tax base, including for Belgium. Third, formula allocation will lead to a re-allocation of the tax bases across countries, with a small gain expected for Belgium, according to the EC's impact assessment (EC, 2016). Finally, the СССТВ can put further pressure on Belgium to lower its statutory CIT rate, which will be the only remaining instrument to attract business investment.

\subsection{Tax competition}

Within the boundaries of the EU directives and the BEPS minimum standards, the European countries compete for mobile capital by providing attractive fiscal terms for FDI. For one part, the countries have introduced targeted preferential regimes, including through innovation boxes, which primarily serve to attract mobile tax bases from MNCs. For another part, they engage in tax competition using their headline CIT rates. For instance, the empirical tax competition literature provides firm ground for strategic complementarity in CIT rates, implying that countries respond to the reductions in CIT rate elsewhere by lowering their own (IMF, 2014). During the past three decades, this has induced a gradual decline in the CIT rates in Europe. Figure 7 illustrates this trend since 2001 in the Euro area and Belgium: in the Euro area, the mean CIT rate

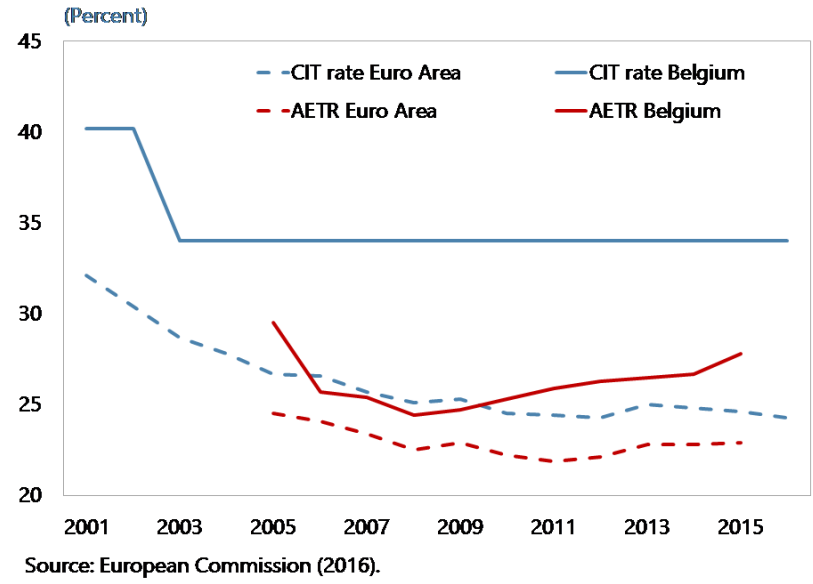

Figure 7: Trends in CIT Burden in Belgium and the Euro Area

dropped from 32.1 to 22.5 percent; in Belgium, it fell by less from 40.2 to 34 percent. Further, the AETR declined over the past decade, namely from 24.5 percent to 22.9 percent in the Euro Area and from 29.5 to 27.8 percent in Belgium. Although the pace of tax cuts in Europe has somewhat stalled during the last few years, several countries have recently announced further reductions.

In light of this international tax competition, the relatively high CIT rate in Belgium imposes two important risks:

- BEPS risk. The high rate makes the Belgian tax base of multinational companies increasingly vulnerable to BEPS behaviors. Indeed, the incentive for MNCs to shift profits out of Belgium to lowtax jurisdictions is governed by the difference in statutory tax rates with other countries. Empirical studies, for instance, suggest a robust relationship between tax rate differentials and measures of reported profitability (Dharmapala, 2014; Heckemeyer and Overesch, 2013).

- Relocation risk. The high CIT rate is an important component of the relatively high AETR in Belgium compared to other countries. This makes Belgium less attractive for foreign investors who seek a location for their new businesses through greenfield FDI. ${ }^{19}$ Tax competition thus puts increasing pressure on Belgium to also lower its CIT rate. Of course, as long as reductions in the CIT rate are financed by

19 Keen (2001) shows that limitations for countries to compete for mobile capital by means of preferential tax regimes will intensify tax competition based on the general tax rate. The latter form of tax competition might induce larger welfare losses than the former, since the tax burden on immobile economic rents will also be reduced. 
base broadening, the mean value of the AETR across Belgian firms will not decline; reductions for some companies will then be merely offset by increases for others. The net effect on firm location will therefore be uncertain and dependent on the responsiveness of various types of capital to tax. Yet, lowering the statutory CIT rate might have the additional advantage of providing more certainty to international business compared to targeted incentives in the tax base that have come under increased international scrutiny. This tax certainty can be an important consideration as well for FDI locations by MNCs.

\subsection{Fiscal Constraints}

A reduction in the CIT rate without offsetting measures would result in revenue loss. The High Council of Finance (2016) has considered the opportunities for a CIT rate cut in Belgium to either 25 or 20 percent. With a CIT revenue productivity of 0.1 percent of GDP and without the compensating measures, this would imply a static revenue loss of 0.9 and 1.4 percent of GDP, respectively. The revenue loss might be smaller, however, if dynamic scoring effects are considered, that is, the broadening of the tax base due to endogenous responses to the lower rate. Such effectswhich may occur primarily in the medium to longer termare captured by the elasticity of corporate taxable income, that is, the percentage change in the tax base due to a one percentage point change in the CIT rate. Based on a survey of the available international evidence, De Mooij and Saito (2014) arrived at a consensus value of -0.2 for this elasticity. Hence, every $€$ tax relief granted through a lower CIT rate will ultimately cost the government 80 cents. This would mean that rate cuts to 25 and 20 percent would, in the long run, cost approximately 0.7 and 1.1 percent of GDP, respectively. Clearly, these are still sizable revenue losses. Moreover, if base broadening measures are adopted to compensate for this revenue loss, these themselves might induce opposing dynamic effects by exacerbating the distortionary impact of the CIT. Caution is therefore required in allowing dynamic scoring effects to determine the revenue implications of the reform. Given that Belgium faces tight fiscal constraints and has limited scope for shifting the tax burden away from corporations (given the already high taxes on labor and consumption), cuts in the CIT rate should be accompanied by offsetting measures either within the CIT system, or to other capital income taxes on individuals.

CIT reform would also need to consider effects on tax neutrality in the business legal form, with a view to lim-

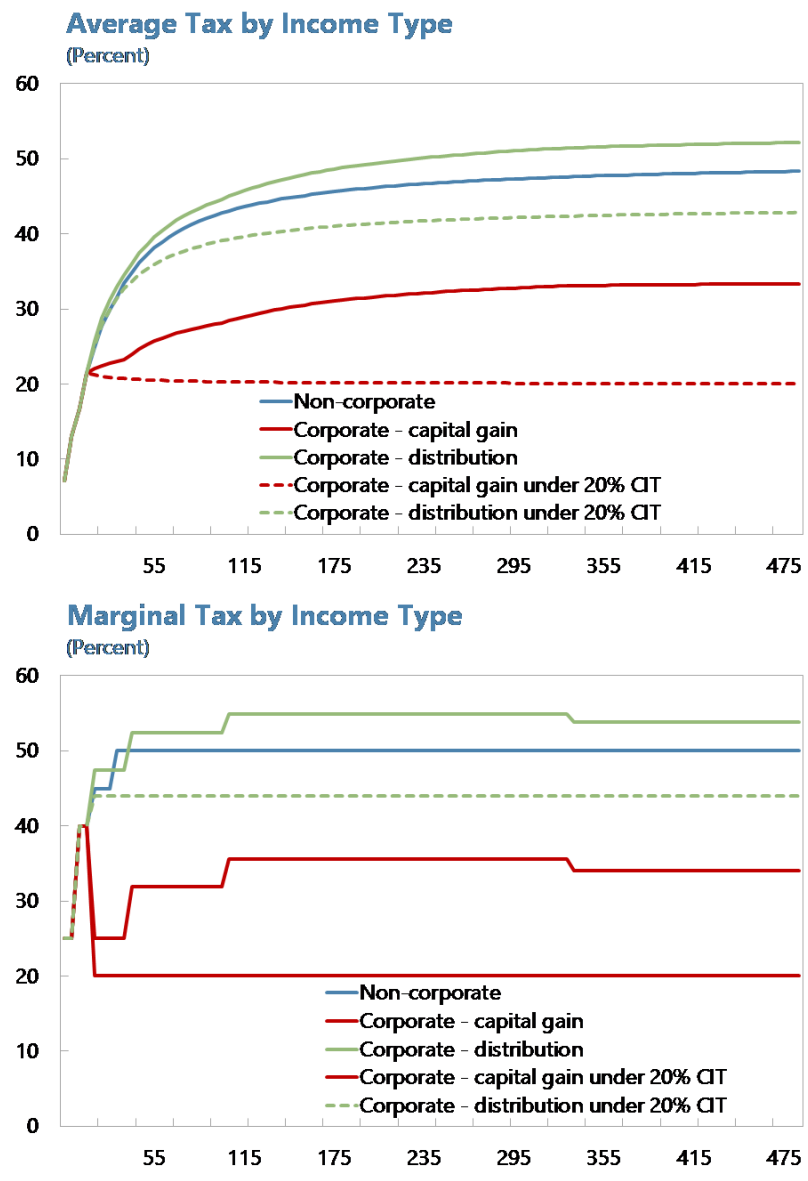

Source: Author calculations.

Figure 8: CIT Reform and Non-Neutrality Among Different Types of Business Income

iting distortions and tax arbitrage. Figure 8 shows what would happen with the average and marginal tax rates on different types of business incomes (as in Figure 3), if the CIT rate structure were reduced from the current progressive structure to a uniform 20 percent rate (dotted lines). Thereby, it is assumed that withholding taxes on dividends and PIT rates on non-corporate business income remain unchanged. We see that the marginal and average tax burden for distributed corporate profits are moved well below those for non-corporate business income, thus inducing a stronger incentive for businesses to incorporate. This could broaden the CIT base, but would come at the expense of a narrower base of the PIT (and reduce the level of social security contributions). For retained profits, the current tax preference will be reinforced further by the CIT rate cut and will thus induce an even stronger incentive to realize income as a capital gain. 


\section{Options for Growth-Enhancing Reform}

Policies of CIT base broadening and rate reduction (BB\&RR) have been prevalent across the globe during the past few decades. Kawano and Slemrod (2016), for example, have collected information about CIT rate and base changes in 30 OECD countries between 1980-2004. They record a total of 134 CIT rate cuts and 302 base broadening measures (at the same time, there were also 37 CIT rate increases and 229 base narrowing measures).

Despite its popularity, however, not all forms of $B B \& R R$ are growth enhancing. A reduction in the headline CIT rate cut can promote investment, employment and productivity by itself. However, base broadening measures to finance such a rate cut can have an opposite effect. The importance of the latter depends on the type of base broadening. Some incentives, for instance, might be efficient ways to encourage investment or innovation; others, in contrast, can distort the level playing field across firms or magnify existing distortions. A case-by-case approach is therefore required to assess the economic merits of various base-broadening measures, necessary to finance a cut in the CIT rate. Below, we provide a brief assessment of the main options, thereby making use of High Council of Finance (2016).

\subsection{Base broadening}

The system in Belgium before 2018 had a range of options for base broadening that would help balance growth and revenue objectives.

- New measures against tax avoidance are part of Belgium's obligation to comply with European ATAD. Interest deduction limitations, CFC rules and exit taxes could expand the Belgian CIT base and boost revenue. This additional revenue would come entirely from large MNCs.

- Repeal of the special CIT rates for SMEs could be good for growth. A proportional CIT is more efficient than progressive CIT rates, as the latter disincentivize firms from growing larger (IMF, 2016b). Progressive CIT rates could also induce firms to split their business in multiple parts to optimize the preferential treatment, with negative implications for organizational efficiency. Distributional considerations also provide little rationale for progressivity in the CIT, as the connection between the income of a legal entity and the personal income of the owners is often weak or absent.

- Some CIT exemptions and deductions could be curtailed with only marginal growth effects. For instance, it would be useful to review the efficiency of several special deductions, for example, internships, cars, gifts and restaurants. The High Council of Finance (2016) found that the combined effect of those measures could broaden the CIT base such that the CIT rate could be reduced by several percentage points.

- The innovation box regime could be reformed. A study by Dumont (2015) found that the Belgian innovation box has had no significant effect on R\&D. While the Belgian innovation box has been made less generous in 2017 to comply with the new international standards, the Belgian government simultaneously increased the exempt amount from 80 to 85 percent and widened the range of qualifying IP assets to include copyrighted software and qualified orphan drugs. To support innovation, however, it would have been more effective to expand instruments that directly reduce the cost of $R \& D$.

Some options for base broadening are less promising, and there are some areas where the current regime is already quite restrictive.

- Making depreciation allowances less generous could boost the CIT base during the first few years after the reform; yet, they will have no structural revenue implications. In fact, since less generous tax depreciation allowances will raise the book value of assets in the tax accounts, they will increase the cost of the NID in later years. Indeed, the present value of the sum of depreciation allowances and the NID allowance is independent on the rate at which firms write down their assets.

- R\&D tax incentives are important instruments for promoting innovation. For instance, IMF (2016b) concludes that, when designed and implemented properly, R\&D tax incentives have the potential to yield a sizable impact on productivity growth. A recent evaluation by Dumont (2015), using the Belgian micro data, finds that especially the tax relief for wages of researchers exerts a significant positive impact on R\&D investment in Belgium.

- Loss offset provisions, which are critical for investment and growth, are already restrictive. Less generous loss offset would discourage entrepreneurs to experiment and undertake risk, which is vital for innovation (IMF, 2016b). Empirical evidence also 
finds that limitations to loss offset significantly reduce the level of investment (Dreßler and Overesch, 2013). In Belgium, the absence of: (i) a consolidation regime; (ii) loss carry backward provisions; and (iii) interest on deferred losses, already impose important limitations to loss offset. Further restrictions will likely hurt economic growth. In fact, to enhance growth, Belgium could consider expanding loss offset provisions, for example, by adopting a consolidation regime.

\subsection{Supporting tax neutrality}

There are several options for restoring balance between different forms of business income and limiting tax arbitrage. As discussed above, a reduction in the CIT rate would aggravate the tendency for tax arbitrage and excessive incorporation of small businesses.

- A higher dividend withholding tax would be one option that could restore tax neutrality between salary payments and dividend payments, if the CIT rate is reduced. Moreover, introducing a capital gains tax could help address the increased imbalance between distributions and retained earnings. ${ }^{20}$ However, this suggests the need for a wider review and analysis of business and investment income taxation in Belgium (including, for instance, capital transaction taxes) to infer the precise implications, which is beyond the scope of this paper.

- Allocation rules for domestic businesses could also be strengthened. For instance, Nordic countries impute a "normal" rate of return to some measures of business capital (gross or net assets), with the residual income allocated to labor income. Thus, businesses with little investment, whose value-added is derived largely from labor, are subject to the progressive PIT on most of their income. The challenge with such allocation rules, however, is with the enforcement, which can be complex.

- If small corporations are pass-through entities, the owners could be taxed on all their assigned income at the progressive PIT.

20 The imbalance between retained and distributed profits could also be addressed by imposing tax on a so-called deemed distribution, that is, a fictitious amount that is deemed to be distributed irrespective of the actual distribution. The United States, for example, assume such a deemed distribution on personal holding companies that could otherwise shelter retained earnings as passive income.

\subsection{Strengthening the growth properties of the NID}

The NID could be reformed to both enhance its growthpromoting properties and mitigate its undesirable spillover effects to other countries through tax planning. The Belgian NID deviates in several ways from a model ACE design, which is discussed in more detail in Annex 2. This reduces its effectiveness in encouraging investment and financial stability. Therefore, several aspects of the NID may warrant reconsideration:

- As discussed above, the Belgian NID rate is linked to the government bond rate. However, the appropriate rate necessary to exploit the neutrality features of the NID should be higher to account for the corporate risk. The Annex, for example, argues that a risk premium of 2 or 3 percentage points could be added to the long-term government bond rate. While this would support investment and growth, it also increases the revenue cost of the NID. To mitigate these fiscal implications, Belgium could implement this additional risk premium on an incremental basis, that is, only for equity increases relative to the year of introduction. While this would preserve the incentive effects of the NID for new investments, it would avoid providing a windfall gain for the existing stock of equity.

- Restoring the carry forward of unused NID is an option that would strengthen the incentives to invest. It would imply more certainty that the NID can indeed be used, even if a firm incurs current losses. Moreover, it would also help absorb macroeconomic shocks by mitigating financing constraints that tend to be cyclical.

- The use of the NID by SPVs as a form of international tax planning could be curtailed by imposing an anti-avoidance rule that declines the NID provision in specific circumstances (Zangari, 2014). The price paid will likely be the departure of most SPVs from Belgium, as the tax planning route that justifies their existence is cut off. Yet, the impact on the real economy in Belgium is likely to be small.

- As discussed in Annex 2, if the value of participations on a firm's balance sheet exceeds the value of its equity (e.g., in a holding company that finances share participations with debt), the NID base is negative. While this should in principle give rise to an addition to the tax base for that holding company, the NID base in Belgium is capped at zero. This creates opportunities for domestic tax planning, as the 
zero lower bound can imply duplication of NID relief IMF (2016a). Eliminating the zero lower bound on the NID base is the most direct way to address this form of domestic tax avoidance and restore the neutrality of the NID. Alternatively, anti-avoidance provisions may prevent this form of tax planning, for example, interest deductions could be disallowed for debt that is used solely to finance equity participations.

\section{Conclusions}

In 2018, the Belgian government made a start with the implementation of several changes to the CIT system, including a gradual reduction of the statutory CIT rate from 34 to 25 percent in 2020. It also implemented the antiavoidance package of the EU, a tax consolidation regime and a streamlining of the provisions for small businesses. These reforms can be characterized as strengthening the robustness of the system and are likely to be conducive to growth. Yet, the reform also includes changes that are likely to be the opposite. In particular, with respect to the NID, the government effectively repealed the current system and replaced it with an incremental NID of limited duration. Specifically, starting form 2018, the base of NID will be the incremental equity in excess of the average equity of the preceding five years. This is a significant reduction that may have negative implications for growth and economic resilience in Belgium. First, past investments have been made under the assumption that the old NID would remain in place. Eliminating it will raise the tax on these investments, which reflects a classic example of a time inconsistent policy: the government increases the tax on investment returns; after that, capital has been installed and sunk costs have been absorbed. This can have repercussions for the credibility of Belgium government, rendering the new incremental NID ineffective as investors may fear for future repeal. In general, an incremental system has significant appeal for countries only when introducing a new NID (as past investments have already been made without the allowance). Once implemented, an incremental NID will gradually evolve into an ordinary one, as more equity becomes incremental relative to the introduction date. A second weakening of the NID relates to its temporary nature, that is, incremental relative to the fiveyear average. This re-introduces debt bias, since interest will be deductible without time limitation while the notional interest on equity will become deductible for a limited period. This also reduces the favorable impact on the cost of capital, and therefore investment, especially those with a longer time span. Instead of limiting the scope of the NID, this provision could have been strengthened to fully achieve its neutrality effects (on financial structures and investment), while anti-tax avoidance provisions could have helped reduce tax planning.

The reform could have also strengthened neutrality in organizational form, that is, between corporate and noncorporate businesses. Indeed, the reduction in the CIT rate (as well as the lower rate for profits up to €100,000) exacerbate distortions in favor of incorporation. More neutrality could have been achieved in several ways, including by introducing a personal tax on capital gains and raising the dividend tax.

\section{References}

Abadie, A., A. Diamond, and J. Hainmueller, 2010, Synthetic Control Methods for Comparative Case Studies: Estimating the Effect of California's Tobacco Control Program, Journal of the American Statistical Association 105 (490), 493-505.

Aus dem Moore, Nils, 2014, Corporate Taxation and Investment: Evidence from the Belgian ACE Reform, Ruhr Economic Papers 534.

Brekke, K., Garcia Pieres, A., Schindler, D., and Schjelderup, G., 2017, Capital taxation and imperfect competition: ACE vs. CBIT, Journal of Public Economics 147, 1-15.

Boadway R. and N. Bruce, 1984, A General Proposition on the Design of a Neutral Business Tax, Journal of Public Economics 24, 231-39.

Bond, S.R. and M.P. Devereux, 1995, On the Design of a Neutral Business Tax Under Uncertainty, Journal of Public Economics 58, 57-71.

Burggraeve, K., Ph. Jeanfils, K. van Cauter, and L. van Meensel, 2008, Macroeconomic and Fiscal Impact of the Risk Capital Allowance, National Bank of Belgium, Economic Review.

De Mooij, R., and M.P. Devereux, 2011, An Applied Analysis of ACE and CBIT. Reforms in the EU, International Tax and Public Finance 18, 93-120.

De Mooij, R. A., and Gaetan Nicodeme, 2008, Corporate Tax Policy and Incorporation in the EU, International Tax and Public Finance 15, 478-98.

De Mooij, R.A., and I. Saito, 2014, Japan's Corporate Income Tax: Facts, Issues and Reform Options, IMF Working Paper 14/138.

Dharmapala, D., 2014, What do we Know About Base Erosion and Profit Shifting? A Review of the Empirical Literature, Fiscal Studies 35, 421-448.

Dreßler, D. and M. Overesch, 2013, Investment Impact of Tax Loss Treatment - Empirical Insights from a Panel of Multinationals, International Tax and Public Finance 20, 513-543.

Dumont, M., 2015, Evaluation of federal tax incentives for private R\&D in Belgium: An update, Federal Planning Bureau Working Paper 515.

Duprez, C., and Van Nieuwenhuyze, C., 2016, Belgium Inward and Outward Foreign Direct Investment, National Bank of Belgium Economic Review, Brussels.

European Commission, 2016, Taxation Trends in the European Union. 
Federal Public Service Finance, 2016, Federal Tax Expenditures Report.

Fuest, C., Peichl, A., and Siegloch, S, 2015, Do Higher Corporate Taxes Reduce Wages? IZA Discussion Paper No. 9606.

Hebous, S., and Ruf, M., 2017, Evaluating the Effects of ACE Systems on Multinational Debt Financing and Investment, Journal of Public Economics 156, 131-149.

Heckemeyer, J. and M. Overesch, 2013, Multinational Profit Response to Tax Differentials: Effect Size and Shifting Channels, ZEW Discussion Paper 13-045.

High Council of Finance, 2014, Een Tax Shifting Ten Voordele van Arbeid en Bredere Belastinggrondslagen, August.

High Council of Finance, 2016, Advies: De vennootschapsbelasting in een "Post-BEPS” omgeving, July.

International Monetary Fund, 2014, Spillovers in International Corporate Taxation, IMF Policy Paper, May 2014.

International Monetary Fund, 2015, Toward a Growth-Friendly Fiscal Consolidation in Belgium, Selected Issues, February.

International Monetary Fund, 2016a, Tax Policy, Leverage and Macroeconomic Stability, IMF Policy Paper, October.

International Monetary Fund, 2016b, Fiscal Policies for Innovation and Growth, Fiscal Monitor, April.

Kawano, L. and J. Slemrod, 2016, How do Corporate Tax Bases Change when Corporate Tax Rates Change? With Implications for the Tax Rate Elasticity of Corporate Tax Revenues, International Tax and Public Finance 23, 401-433.
Keen, M., 2001, Preferential Regimes Can Make Tax Competition Less Harmful, National Tax Journal 54, 757-62.

Kerste, M., B. Baarsma, J. Weda, N. Rosenboom, W. Rougoor, 2013, Uit de schaduw van het bankwezen (in Dutch), Stichting voor Economisch Onderzoek (SEO), University of Amsterdam.

Kestens, K., P. Van Cauwenberge and J. Christiaens, 2012, The Effect of the Notional Interest Deduction on the Capital Structure of Belgian SMEs, Environment and Planning C-Government and Policy 30, 228-247

Mirrlees, J., Adam, S., Besley, T., Blundell, R., Bond, S., Chote, R., Gammie, M., Johnson, P., Myles, G., and Poterba, J., 2011, Tax by Design: The Mirrlees Review, Oxford University Press, Oxford, UK.

Panier, F., F. Perz-Gonzalez and P. Villanueva, 2015, “Capital Structure and Taxes: What Happens when you (also) Subsidize Equity?”, Paper presented at the Bank of International Settlements.

Princen, S., 2012, Taxes Do Affect Corporate Financing Decisions: The Case of Belgian ACE, CESifo Working Paper No. 3713. Munich.

Schepens, G., 2016, Taxes and Bank Capital Structure, Journal of Financial Economics 120, 585-600.

Zangari, E., 2014, Addressing the Debt Bias: A Comparison between the Belgian and the Italian ACE Systems, European Commission Working Paper N.44 - 2014, Brussels.

Zentrum für Europäische Wirtschaftsforschung (ZEW), 2016, Effective Tax Rates in an Enlarged European Union, Study for the European Commission. 


\section{Annex 1. Group Taxation Regimes in Europe}

Many European countries apply some form of group taxation, based on the assumption that each corporate group forms a single economic unit and should be taxed accordingly. Group taxation allows for the consolidation of losses and profits. The participation threshold defining the members of the consolidated group usually ranges between 50 and 95 percent. Under consolidation, intra-group transactions are eliminated as well as the need to price them at arm's length. The tax base of the consolidated group can be calculated on the entire basis, disregarding shares held by minority shareholders, or as a proportional aggregation (e.g., international tax consolidation in France). A few countries extend group taxation beyond their borders (Netherlands, Denmark, Italy, Luxembourg and Ireland), usually under strict conditions, such as all the qualifying foreign companies must be included in the consolidation.

Austria, Cyprus, Iceland, Finland, Sweden, Ireland, Latvia, Lithuania, Malta, and the United Kingdom do not allow full consolidation of revenues and expenses. However, members of the same group can share their profits or losses within a tax period. The German model requires subordinated members of the group to transfer their profit or loss by means of a formal commercial agreement to the parent company, which presumes all tax liabilities of these members.

Belgium, together with Bulgaria, Croatia, the Czech Republic, Estonia, Greece, Hungary, Romania, Slovakia, Slovenia and Switzerland, do not have a group tax treatment. These countries treat all members of the group as independent taxpayers. They neither allow any transfer of losses to other group companies nor eliminate transfer-pricing issues on intra-group transactions. In these countries, economic inefficiencies can be overcome using branches (not having legal personality) instead of subsidiaries.

\section{Annex 2. Design of a Notional Interest Deduction}

This Annex describes the design of the text-book allowance for corporate equity (or equivalently, notional interest deduction), that aims to fully neutralize distortions of the CIT to financial structure choices and marginal investment decisions.
The NID base is either the entire equity stock, or the increment of equity relative to some base year. For instance, if last year's equity is used as the base year, the system is incremental relative to that stock. In that case, the NID base is formed by new equity issues plus retention of after-tax profits, relative to last year. To avoid duplication of NID, equity participations in other firms should be subtracted from the equity base: these participations will already be included in the equity base of the company that issued the shares. If this leads firms to have a negative balance of equity minus the value of participations in other firms-for example, a holding company that finances participations primarily with debt-the NID will involve an addition to the CIT base, rather than a deduction. In this way, the NID system guarantees tax neutrality between debt and equity also for holding companies, since the negative NID offsets the amount of interest that the holding company is allowed to deduct from taxable profits. It ensures that holding companies have no tax incentive to finance acquisitions by debt rather than equity. Participations in foreign companies should also be excluded from the NID base, since foreign equity returns are not subject to domestic tax.

The NID rate must be equal to the rate at which shareholders discount the tax savings from the company's future NID to obtain full tax neutrality under the NID. This discount rate will depend on the degree of riskiness attached to these tax savings. If the tax law allows full loss offset (including a carry forward of unused NID) and the CIT rate is fixed over time, shareholders will receive the tax benefit from the NID with full certainty. Hence, they will discount the tax savings from the NID system at the risk-free rate of interest (Bond and Devereux, 1995). To ensure tax neutrality, it is then sufficient to set the notional rate of return equal to the risk-free rate, for example, proxied by the interest rate on government bonds. In Belgium, however, losses cannot be carried with interest and unutilized losses when a firm goes out of business cannot be offset against other taxable income. Moreover, unused NID cannot be carried forward since 2013. Hence, there will be some risk attached to the NID deductions. The risk will differ across companies, depending on how much they are affected by the restrictions on loss offsets. A substantial part of the risk is likely to stem from the probability that the company goes bankrupt. This risk will be reflected in the rate of interest at which the firm can borrow, so setting the NID rate equal to the interest on the company's long-term debt would presumably ensure rough neutrality. However, for administrative reasons it is common to use a single NID rate for all companies rather than applying firm-specific rates. The average interest rate on corporate bonds would 
be a natural benchmark for choosing the NID rate. Alternatively, the NID might be based on the government bond rate and supplemented with a risk premium to reflect corporate risk. 